\title{
A INTERCULTURALIDADE DOS DIREITOS HUMANOS E O NOVO CONSTITUCIONALISMO \\ LATINO-AMERICANO \\ $-$ \\ DO \\ UNIVERSALISMO DE PARTIDA AO UNIVERSALISMO DE CHEGADA
}

\author{
Aloísio Krohling ${ }^{1}$ \\ Heleno Florindo da \\ Silva ${ }^{2}$
}

\begin{abstract}
Resumo
O novo constitucionalismo latino-americano surge a partir de um conjunto de novas tendências constitucionais ínsitas à América Latina, sobretudo a partir das três últimas décadas, tracejando-se a partir de uma nova perspectiva política, social, econômica e cultural, capaz de fixar importantes instrumentos para a libertação e a emancipação, necessárias a transformação da realidade da grande maioria dos latino-americanos que ainda hoje vivem à margem da sociedade política de seus Estados. É a partir dessa perspectiva que o presente trabalho buscará analisar o aspecto monocultural dos direitos humanos inerente à sua racionalidade universalizante, tal como construída durante a formação, sobretudo, dos Estados constitucionais e, em especial, após o fim da Segunda Guerra Mundial, com a Declaração Universal dos Direitos Humanos, objetivando lançar o debate sobre a necessidade de sua reconfiguração a partir de uma racionalidade intercultural de libertação e de emancipação de todos que, diferentemente do Eu moderno, ainda não possuem os meios necessários para usufruir, universalmente, de um mínimo de dignidade.
\end{abstract}

Palavras-chave: Direitos Humanos; Universalização; Novo Constitucionalismo Latinoamericano; Interculturalidade.

\footnotetext{
${ }^{1}$ Pós-doutor em Filosofia Política e Ciências Sociais pela Pontifícia Universidade Católica de São Paulo PUC/SP. Doutor de Filosofia pelo Instituto Santo Anselmo - Roma, Itália, reconhecido como titulação de PH.D. em Filosofia pela Universidade Federal do Espírito Santo - UFES. Mestre em Teologia e Filosofia pela Universidade Gregoriana - Roma, Itália, e em Sociologia Política pela Escola de Sociologia e Política de São Paulo. Graduado em Filosofia pela Faculdade Anchieta - São Paulo, e em Ciências Sociais pela Loyola University, Chicago, USA. Professor permanente do Curso de Pós Graduação Estrito Sensu (Mestrado e Doutorado) da Faculdade de Direito de Vitória (FDV). Pesquisador e Membro do Grupo de Pesquisa “ Múltiplo Retórico e Dialético: ética, interculturalidade e direitos humanos fundamentais na história das ideias jurídicas no Brasil”. E-mail: krohling@gmail.com

${ }^{2}$ Doutorando em Direitos e Garantias Fundamentais pela Faculdade de Direito de Vitória (FDV). Mestre em Direito em Direitos e Garantias Fundamentais pela Faculdade de Direito de Vitória (FDV). Especialista em Direito Público pelo Centro Universitário Newton Paiva. Bacharel em Direito pelo Centro Universitário Newton Paiva. Membro do Grupo de Pesquisa Estado, Democracia Constitucional e Direitos Fundamentais da Faculdade de Direito de Vitória (FDV). Membro Diretor da Academia Brasileira de Direitos Humanos (ABDH). Professor no Curso de Direito da Faculdade Multivix Cariacica. Coordenador Geral do Curso de Direito da Faculdade Multivix Cariacica. Professor do Centro de Evolução Profissional (CEP). E-mail: hfsilva16@hotmail.com.
} vol.09, n. 03, Rio de Janeiro, 2016. pp. 


\section{INTRODUÇÃO}

"Temos o direito a ser iguais quando a diferença nos inferioriza, e temos o direito a ser diferentes, quando essa igualdade nos descaracteriza" (Boaventura de Sousa Santos).

Vivemos ${ }^{3}$ um tempo de muitas angústias e questionamentos sobre nossa vida, nossos problemas e, em especial, sobre o modo como resolvemos esses problemas, essas angústias e esses questionamentos, ou seja, é um tempo em que não somente as perguntas nos afligem, mas, também, suas respostas.

Será a partir desse cenário de profunda desordem no consciente político, social, econômico e cultural da humanidade, que buscaremos compreender como as novas tendências democráticas latino-americanas, fruto do que se convencionou chamar de novo constitucionalismo latino-americano ${ }^{4}$, que surgem através de inúmeros movimentos sociais, verdadeiras lutas em busca de um novo horizonte, de uma profunda libertação dos excluídos, podem nos servir para amenizarmos alguns desses problemas, inerentes ao estudo dos direitos humanos - tais como a necessidade de sua proteção e efetivação -, bem como das respostas que são encontradas as tais situações - como, por exemplo, a universalização dos direitos humanos, sobretudo, desde a segunda metade do século passado, a partir da Declaração Universal dos Direitos Humanos.

A partir de então, buscaremos resposta ao seguinte problema de pesquisa: é possível extrairmos uma nova racionalidade, a partir das novas tendências constitucionais latinoamericanas, hoje conhecidas e difundidas como novo constitucionalismo latino-americano, necessária ao debate e a construção de uma visão intercultural dos Direitos Humanos que sejam, substancial e fundamentalmente, diversas daquilo que foi, e ainda é, posto pelo paradigma moderno e universalizante desses direitos?

\footnotetext{
${ }^{3}$ Como ponto de referência para a construção do presente texto será usada linguagem pessoal, na primeira pessoa do plural, haja vista o objetivo do presente trabalho ser compreender a necessidade de "nós", latinoamericanos, observarmos nossas peculiaridades enquanto diversidade epistemológica, algo refletido na Filosofia do Direito Latino-americana, em diálogo com o paradigma euro-norte americano de cariz colonizador. Desta feita, em que pese o melhor estilo de construção narrativo-metodológica, ser o impessoal, por tais motivos, optou-se pelo presente estilo de narrativa.

${ }^{4}$ Trata-se de um "constitucionalismo que pode romper com o que se considera como um dado, algo imutável, e que poderá avançar pelo caminho da justiça social, da igualdade e do bem-estar dos cidadãos" (PASTOR e DALMAU, 2013, p. 5 - tradução nossa).
} vol.09, nº. 03, Rio de Janeiro, 2016. pp. 
Com o objetivo de alcançar uma resposta satisfatória ao presente problema de pesquisa, partiremos, através de uma perspectiva metodológica do múltiplo-dialético ${ }^{5}$, de uma visão crítica dos Direitos Humanos, uma percepção teórica que vê os Direitos Humanos a partir das bases ideológicas trazidas pela modernidade - e que ainda são as atuais em se tratando desses direitos -, ou seja, fixando os Direitos Humanos como mais um importante instrumento moderno de dominação, de encobrimento e marginalização do outro, do diferente, do diverso.

Para tanto, num primeiro momento, buscaremos apresentar a formação universalizante dos direitos humanos, através de uma perspectiva teórica exposta, sobretudo, por Joaquim Herrera Flores, capaz de nos conduzir a conclusão de que o universalismo inerente a acepção moderna de direitos humanos - ainda hoje presente nos discursos políticos, econômicos, sociais e culturais, seja na academia ou fora de seus muros - é um tipo de universalismo de partida, excludente e homogeneizante, indiferente à diversidade contemporânea, de modo que se faz necessário debatermos tal perspectiva universalizante a partir do que se denominou no decorrer do trabalho de universalismo de chegada.

Após serem debatidas as perspectivas universalizantes dos direitos humanos na primeira parte deste trabalho, num segundo momento efetivamos a análise das novas tendências constitucionais latino-americanas, ínsitas ao que hoje se chama de novo constitucionalismo latino-americano.

E é, portanto, a partir dessas novas tendências, que buscamos, através da presente pesquisa, analisar e debater ${ }^{6} \mathrm{o}$ caráter monocultural dos direitos humanos, tal qual os concebemos, em decorrência das características dos paradigmas da modernidade, a fim de que nos fosse possível debater, a partir do novo constitucionalismo latino-americano, instrumentos capazes de reconfigurar, plural e interculturalmente, essa visão ínsita à universalidade dos direitos humanos.

\footnotetext{
${ }^{5}$ Para um melhor aprofundamento acerca do método de pesquisa identificado aqui como Múltiplo Dialético, ver KROHLING, Aloísio. Dialética e Direitos Humanos - múltiplo dialético: da Grécia à Contemporaneidade. Curitiba: Juruá Editora, 2014.

${ }^{6} \mathrm{O}$ debate sempre deve ser possível, mesmo que se dê frente a padrões conceituais que, de tão arraigados, começam a se cristalizar a ponto de se transformarem em ideologias acabadas e indiscutíveis (ZIZEK, 2010). Desse modo, como bem como apontam SANTOS, André Leonardo Copetti e LUCAS, Doglas Cesar (2015, p. 75) "a teorização da diferença, ao permitir reproposições e redimensionamentos do espaço público, como lugar de produção da política e do jurídico (com ordem simbólica), produziu um faturamento de objetos de conhecimento tradicionalmente fechados, tornando- -os abertos, inacabados, imprevisíveis, em muitos aspectos previamente impensados, portanto incontroláveis pelas normas de produção das verdades científicas que estavam há longo tempo estabelecidas".
} vol.09, $\mathrm{n}^{\circ} .03$, Rio de Janeiro, 2016. pp. 


\title{
A MODERNIDADE E OS DIREITOS HUMANOS ${ }^{7}$ : DO UNIVERSALISMO DE PARTIDA AO UNIVERSALISMO DE CHEGADA ${ }^{8}$
}

\author{
A Construção Universal e Homogeneizante da Modernidade como Local de \\ Desenvolvimento de um Discurso de Exclusão da Diversidade
}

Antes de analisarmos o novo constitucionalismo latino-americano e a possibilidade, ou não, de extrair de suas bases teórico-sociais uma concepção intercultural para os direitos humanos, é necessário compreendermos como o debate sobre direitos humanos será desenvolvido neste trabalho, ou seja, qual é a matriz teórico-filosófica usada como referencial para a análise dessa construção histórica dos direitos humanos, bem como de sua concepção universalizante.

\footnotetext{
${ }^{7}$ Antes de darmos início a nossa análise da possibilidade de reconstrução intercultural, a partir da racionalidade inerente ao novo constitucionalismo latino-americano, dos direitos humanos, é importante frisar que ao falarmos desses direitos na presente pesquisa, não restringimo-nos àquelas antigas divisões doutrinárias acerca da territorialidade desses direitos - fundamentais, os Direitos Humanos positivados internamente pelos Estados e, humanos, aqueles descritos na ordem internacional, positivados ou não pelos Estados -, pois quando falamos de direitos humanos, o fazemos a partir de um acordo, de uma convenção, de uma ideologia, que, nos dizeres de Herrera Flores, "aponta a algo que tem mais conteúdo que o puramente formal e que, ao mesmo tempo, nos afasta das visões essencialistas da declaração de 1948" (2009b, p. 161), ou seja, trata-se, com a devida vênia, de uma visão lato senso, da matéria em discussão.

${ }^{8}$ Neste trabalho, nos cabe destacar, as expressões universalismo de partida e universalismo de chegada são empregadas do mesmo modo que aparecem em Herrera Flores (2009b), identificando, no primeiro caso, o fato da compreensão universalizante dos Direitos Humanos, sobretudo a partir da Declaração Universal de 1948, que por, aprioristicamente, considerá-los universais, acabam por afastar a possibilidade de diálogo com todos os povos que não comungam da mesma matriz teórico-política e filosófica que embasa e sustenta referida Declaração. Já frente a segunda expressão, tem-se a necessidade de transformar essa visão universalizante de início em algo a ser construído, ou seja, a necessidade de identificarmos a concepção universalizante dos Direitos Humanos como mecanismo de uniformização cultural desses direitos, de modo que ao percebemo-los como não universais, mas aprioristicamente relativos, damos a todos os povos que não participaram da elaboração da supracitada Declaração, tenham condições de discutir, a partir de suas bases teórico-filosóficas, sociais e políticas, o que identificam por Direitos Humanos, o que nos possibilitará iniciarmos uma caminhada rumo a um diálogo intercultural, cujo fim será um tipo de universalismo de chegada, cujos fundamentos estão arraigados da compreensão do Direito (e ai estão os Direitos Humanos) como um processo histórico e cultural, de conquistas, onde avanços e retrocessos estão presentes constantemente.
} vol.09, $\mathrm{n}^{\circ} .03$, Rio de Janeiro, 2016. pp. 
Para tanto, através de uma teoria crítica dos direitos humanos, sobretudo a partir das construções de Joaquim Herrera Flores, objetivaremos analisar neste primeiro ponto de discussões, as influências da modernidade para a construção do paradigma atual dos direitos humanos, em especial, a partir da Declaração Universal dos Direitos Humanos de 1948.

A modernidade, a partir de então, pode ser vista como elemento necessário para a construção de uma perspectiva universal dos direitos humanos, pois - em que pese haver inúmeras teorias sobre a existência de referidos direitos antes da era moderna, haja vista a existência de cartas de direitos, como a Magna Carta de $1215^{9}$, alguns séculos antes do início da modernidade - é com a modernidade que surge o Estado, as Constituições e a ideia de direitos que são construídos para pertencerem a todos, universalmente.

Daí a necessidade de compreendermos quando se deu o surgimento dessa era moderna, ou seja, a partir de quando é possível perceber que o modelo de organização político-social do feudalismo foi sendo substituído pela figura central do Estado, talvez o principal pilar da racionalidade moderna.

$\mathrm{O}$ ano de $1492^{10}$, neste sentido, é visto aqui - enquanto conceito, pois a história não pode ser vista de forma linear, como um grande encadeamento de atos, mas, ao contrário, como um caminhar cíclico, com idas e vindas - como o momento máximo das discussões que levaram a formação do pensamento moderno.

Ou seja, 1492 é o momento que marca o ápice do amadurecimento dos ideais de superioridade política, social e cultural da Europa em relação aos demais povos do mundo, o que desenrolou um processo de encobrimento de todas aquelas pessoas que não se enquadrassem dentro da estética europeia ${ }^{11}$.

\footnotetext{
${ }^{9}$ Neste sentido ver COMPARATO, Fábio Conder. A Afirmação Histórica dos Direitos Humanos. $8^{\text {a ed. }}$ São Paulo: Saraiva, 2013. p. 58 e 83 e ss.

${ }^{10}$ Apresentando seu entendimento sobre a importância histórica do ano de 1492 , Todorov (2010, p. 7) destaca que nenhuma outra data é tão indicada - apesar de todo termo que separa duas épocas ser arbitrário para demarcar o início da modernidade, do que o ano 1492. (...). E ainda conclui, "os homens descobriram a totalidade de que fazem parte. Até então, formavam uma parte sem o todo".

${ }^{11}$ Acerca da formação moderna de uma estética do ser, podemos perceber que na busca por se tornar potência, verdadeira estética do belo, do correto, daquilo que deva ser seguido, o homem, principalmente, o homem moderno, parte de sua imagem e constrói o seu mundo, dando a ele a sua beleza, o seu modus. Aquilo, que não se enquadrar nesse contexto de beleza formado à imagem do Eu moderno, será construído a golpes de martelo, ou seja, será separado, jogado fora. Sobre a formação dessa estética do Eu - usada aqui para a compreensão da modernidade - Fabriz destaca a construção de Nietzsche a partir do entendimento de potência e impotência, para quem "(...) o homem constrói o mundo à sua imagem e, em contato com aquilo que é obra de suas mãos, é tomado por um forte impulso estético, dimensionado à beleza de sua existência. Em contrapartida - a golpes de martelo -, tudo aquilo que se torna ameaçador ao seu desejo de potência, que o degenera e o torna impotente, assemelha-se ao antiestético, ao feio, à outra face, não semelhante ao mundo construído, que reflete sua imagem”. (1999, p. 70). Assim, é possível concluir que “(...) a filosofia e a cultura ocidentais apostaram, desde seus primórdios na Grécia, em uma reflexão sobre o puro, o incontaminado, o 
Essa identidade do Ser civilizado, objetivada desde o início dos movimentos que marcarão a modernidade, é analisada por Herrera Flores que destacará que essa busca parte do pressuposto de uma essência fixa e independente da variedade de discursos disponíveis por parte dos indivíduos. Ou seja, o termo identidade sugere um sujeito unitário e auto constituinte, cujas características autônomas e primordiais são pré-discursivas por natureza, supostamente constituídas fora da relação social, da história e do poder: raça, o sexo... A identidade é aquilo que se apresenta como naturalmente dado, não como convencionalmente construído (2009b, p. $85)$.

Ainda sobre o período de surgimento e de fixação da racionalidade moderna, Enrique Dussel constrói a ideia de que a modernidade se originou a partir do confronto entre o europeu (Eu) e todos aqueles que não lhe eram semelhantes, aqueles que eram vistos enquanto Outros.

Será a partir do embate entre esse eu e todos os demais outros, que nascerá o pensamento moderno de Ser, ou seja, a modernidade se originou nas cidades europeias medievais, livres, centros de enorme criatividade. Nasceu no momento em que a Europa pode se confrontar com o "outro" e controlá-lo, vencê-lo, violentá-lo; quando definiu-se como um "ego" descobridor, conquistador, colonizador da Alteridade constitutiva da mesma modernidade (1994, p.8 - tradução nossa).

A partir de então é possível concluirmos que essa modernidade, que surge com os delineamentos culturais ínsitos ao modelo político-social europeu, se constituiu a partir do entendimento de que as demais culturas lhes são periféricas, haja vista o fato do outro, negado, dever passar por um processo de modernização a fim que seja reconhecido como sujeito (DUSSEL, 1994, p. 32), o que pode explicar a necessidade de universalização dos direitos humanos ${ }^{12}$.

Ademais, antes de continuarmos a presente análise sobre o modelo racional ínsito aos direitos frutos das construções, sobretudo, constitucionais da modernidade dos Estados nacionais, é necessário destacar, desde já, qual é o significado que damos aos Direitos Humanos.

único, e também num rechaço de tudo que se considerava impuro, contaminado, mesclado, plural” (HERRERA FLORES, 2009a, p. 85).

${ }^{12}$ Essa busca pela universalização dos direitos humanos, pode ser percebida nas Declarações de Direitos das Revoluções Burguesas dos sécs. XVII e XVIII, principalmente na Declaração de Direitos de Virgínia, de 1787 e na Declaração dos Direitos do Homem e do Cidadão de 1789 (HERKENHOFF, 1994, p. 57) vindo a se corroborar com a Carta de 1948. Sob esse ponto, a título de ilustração, ver autores que fazem uma reconstrução da evolução tratativa dos Direitos Humanos, tais como LAFER, Celso. A Internacionalização dos Direitos Humanos. Barueri: Manole, 2005. p. 36-39; PIOVESAN, Flávia. Direitos Humanos e o Direito Constitucional Internacional. 13aed. Rev. e Atual. São Paulo: Saraiva, 2012. Cap. 5. 
Para responder esse questionamento, a presente pesquisa está apoiada, conforme visto acima, na teoria crítica de Joaquim Herrera Flores, para quem “(...) os direitos humanos são produtos culturais que facilitam a construção das atitudes e aptidões que nos permitam fazer nossas vidas com o máximo de dignidade" (2009b, p. 12).

Construindo nossa perspectiva dos direitos humanos a partir das bases postas por Herrera Flores, identificamo-los como construções políticas, sociais e, sobretudo, culturais, ínsitos a cada modo de vida, a cada modelo de organização social, que - mesmo havendo muitos casos em que essas sociedades não irão identificá-los como direitos humanos possuem mecanismos para sua proteção.

Portanto, a universalização buscada aos direitos humanos a partir de suas primeiras formas de declaração já nos séculos XVII e XVIII e, sobretudo, a partir da Declaração Universal dos Direitos Humanos de 1948, deve ser compreendida como mais um movimento da racionalidade homogeneizante e uniformizante da modernidade colonizadora europeia, racionalizada como padrão de civilização para todo o resto do mundo.

É dessa perspectiva crítica do modelo universalizante dos direitos humanos, que Herrera Flores concluirá que ao universalizarmos os direitos humanos a partir das idealizações de determinada configuração desses direitos, retirando-os de seu circuito normal de reação cultural, eles passaram a ser vistos, mais do que como processos culturais, como verdadeiros processos ideológicos, que acabarão dificultando ou impossibilitando ações sociais alternativas ao modelo posto, de cima para baixo, como o melhor para a civilização dos incivilizados, ou seja, (...) o processo da ideologia-mundo baseado na falácia ideológica fecha-se sobre si mesmo e pode apresentar-se diante de qualquer forma de vida como o universal e o racional, sejam quais forem os elementos do contexto que primem em um determinado momento espaço-temporal. (...). Por isso, a ideologia dos direitos humanos universais e descontextualizados (fundamentados no artigo 1.1 da Declaração Universal) é tão funcional aos interesses expansivos e globalizadores do modelo de relaões baseado no capital (2009b, p.71 e 178).

\section{O Universalismo dos Direitos Humanos e a Diversidade - a necessidade de uma análise crítica dos fundamentos teórico, políticos e filosóficos dos direitos humanos universalizantes como ferramenta de uma efetivação da diversidade}

Há, como debatido acima, a necessidade de rediscutirmos o modelo universalizante dos Direitos Humanos, sobretudo em momentos como o atual, cujo modelo de sociedade, pautada $\overline{10101027}$ vol.09, nº. 03, Rio de Janeiro, 2016. pp. 
pela racionalização do mercado globalizado, do capitalismo neoliberal, acaba provocando movimentos migratórios, que muito mais do que econômica, demonstram a crise civilizatória ${ }^{13}$ pela qual a humanidade, contemporaneamente, está passando, de modo que o debate dos direitos humanos deve ser posto à mesa, como um importante mecanismo para reverberar o caráter humano que ainda nos resta.

A partir daí, conforme discutiremos nesta pesquisa, é necessário almejarmos uma reconstrução, uma ressignificação racional dos direitos humanos que, como se verá, deve estar pautada numa matriz intercultural, capaz de visualizar os direitos humanos sob um prisma de emancipação, de libertação de todos aqueles que são Outros frente ao Eu, ou seja, os direitos humanos devem ser estudados e levados à prática politicamente; primeiro, a partir de um saber crítico que revele as escolhas e os conflitos de interesses que se encontram por trás de todo debate cheio de ideologias e, segundo, inserindo-os nos contextos sociais, culturais e econômicos em que necessariamente nascem, se reproduzem e se transformam (HERRERA FLORES, 2009a, p. 56).

Sob o momento civilizatório, que estamos vivenciando nas últimas décadas, visto aqui como um processo desencadeado por alguns movimentos políticos, econômicos e sociais, que se globalizaram, tal como o hiperconsumismo, o individualismo, a extrema e necessária competição do mercado, inerente ao modelo neoliberal da segunda metade do século passado, importante são as palavras de Boaventura de Sousa Santos.

Para ele, são quatro os aspectos fundamentais para identificarmos os pilares articuladores dessa fase neoliberal que o processo de globalização do mercado do capital, visto como um dos principais instrumentos que, ao serem usados, acabaram desencadeando o momento de crise civilizatória em que estamos inseridos, ou seja:

a) proliferação de centros de poder - o poder político nacional vê-se obrigado a dividir soberania com as corporações privadas e organismos globais multilaterais, tais como: o Fundo Monetário Internacional (FMI); b) inextrincável rede de interconexões financeiras do capital - que fazem depender as políticas públicas e a constituição econômica nacional de flutuações econômicas imprevisíveis para o tempo com o que joga a práxis democrática nos Estados Nação; c) dependência de uma informação - que voa em tempo real e é caçada pelas grandes corporações privadas com maior

\footnotetext{
${ }^{13}$ Uma crise que, dia após dia, vítima inúmeras pessoas que, na tentativa de buscar melhores condições de vida em outros países, se arriscam em travessias oceânicas ou terrestres, e que, acaba corroborando aquilo que Arendt, em outro contexto, chamou de banalização do mal. Fazendo referência a teoria dos Direitos Humanos e, principalmente em relação ao que Arendt disse sobre essa "banalização do mal", Herrera Flores nos demonstra que "a maior das banalizações do mal consiste em não considerar que a verdadeira desumanização é a que impede que a maioria da humanidade tenha condições para poder fazer valer com liberdade e igualdade suas propostas, convicções e modelos de organização" (2009b, p.52).
} 
facilidade que pelas instituições estatais e, por fim, d) do ataque frontal dos direitos sociais e laborais - que está provocando que a pobreza e a tirania convertam-se em vantagens comparativas para atrair investimentos e capitais - (2002, p. 25-102 - grifos nossos).

Portanto, "o sistema de valores hegemônicos em nossos dias é majoritariamente neoliberal e, por conseguinte, coloca por cima as liberdades funcionais ao mercado e por baixo as políticas públicas de igualdade social, econômica e cultural" (HERRERA FLORES, 2009a, p. 47).

Isso nos conduzirá à conclusão de que nem todos têm, por igual, os instrumentos e meios necessários à luta pelo acesso aos bens essenciais à dignidade humana, instrumentos de libertação e de emancipação dos excluídos, ou seja, nos demonstra que construção paradigmática da universalidade dos direitos humanos na modernidade, a mesma que ainda hoje embasa o discurso dos direitos humanos mundo a fora, não foi - e não é - capaz de promover as transformações necessárias em uma sociedade global, cada dia mais, em todos os sentidos, plural.

Sob tais perspectivas, para Herrera Flores “(...) vivemos em um mundo subsumido globalmente no capital ${ }^{14}$ e em suas justificações ideológicas" (2009b, p. 2). Portanto, estamos vivendo num mundo onde as relações sociais que o sistema do mercado do capital ${ }^{15}$ nos impõe, se globalizaram através de tecnologias, de intervenções culturais e de novas formas de colonização econômicas.

Enquanto humanidade, estamos inseridos num mundo subsumido "universalmente" ao capital e às suas justificações e necessidades que se pautam numa ideologia neoliberal do pós guerra fria, de modo que definitivamente, entramos num momento histórico “(...) em que a extensão e a generalização do mercado - que se proclama falaciosamente como "livre" - fazem com que os direitos comecem a ser considerados como "custos sociais" das empresas, que devem suprimi-los em nome da competitividade" (HERRERA FLORES, 2009a, p. 31).

A partir de todas essas indagações e conclusões, é possível percebermos a necessidade existente de realizarmos, criticamente, uma busca pela (re)construção de uma visão aos direitos

\footnotetext{
${ }^{14}$ Acerca da influência do mercado nas decisões do Estado, bem como das pessoas em sociedade, José Alberto Mujica Cordano - presidente da República Oriental do Uruguai - chega à conclusão de que vivenciamos um tempo em que "o capital governa os governantes" - discurso proferido na ocasião da conferência da Organização das Nações Unidas para assuntos climáticos (Rio+20).

${ }^{15}$ Neste ponto, é importante destacar que o capitalismo é um mecanismo político, econômico, social e cultural importantíssimo para o processo de um padrão, de um modelo de sociedade que, necessariamente, deveria ser replicado, pois, como destaca Herrera Flores, a partir de seus ideais estaremos “(...) diante de uma racionalidade que universaliza um particularismo: o do modelo de produção e de relações sociais capitalista, como se fora o único modelo de relação humana" (2009a, p. 160).
} 
humanos que os transforme, principalmente, num instrumento ${ }^{16}$ a partir do qual se construa uma nova racionalidade para o sentido de justiça, de equidade, de igualdade, de respeito.

Uma racionalidade intercultural, capaz de, não somente levar em consideração, mas transformar a realidade de exclusão de quase $80 \%$ da humanidade em relação aos benefícios promessas - da nova ordem global - neoliberal e capitalista - promovendo sua emancipação e, principalmente, sua libertação política, social, econômica e, sobretudo, cultural, tão necessária para a concretização universal dos direitos humanos.

Boaventura reconhece essa necessidade ao analisar o problema da separação entre os indivíduos, ínsito ao modelo econômico, político e social promovido pelo sistema global do mercado do capital, ao destacar que:

A divisão é tal que o "outro lado da linha" desaparece enquanto realidade, torna-se inexistente, e é mesmo produzido como inexistente. (...). Tudo aquilo que é produzido como inexistente é excluído de forma radical porque permanece exterior ao universo que a própria concepção aceite de inclusão considera como sendo o Outro. (...). Para além dela há apenas inexistência, invisibilidade e ausência não dialética (2007, p. 3-4) ${ }^{17}$.

Essa racionalidade de resistência - necessária à emancipação dos excluídos - ao modelo de racionalidade ínsito aos direitos humanos a partir dos padrões modernos ocidentais, exposta acima, a partir, principalmente de Herrera Flores, busca conduzir a humanidade à formação de um universalismo de contrastes, de entrecruzamento, de mesclas, entre culturas.

Ou seja, busca-se efetivar um universalismo visto de forma impura, se comparado com o modelo tradicional dos Direitos Humanos, que propõe uma inter-relação de matriz intercultural desses direitos, e não a superposição de um modo de vida sobre os demais, que acaba sendo utilizado como justificativa, como moeda de troca, para quaisquer atrocidades ${ }^{18}$.

Um universalismo de partida ou de retas paralelas, que desde sua gênese já se colocará como o padrão, o modelo universal a ser imposto e respeitado por toda humanidade como critério de aferição de civilidade ou não de um povo, ou seja, que parte do eu, do igual, do

\footnotetext{
${ }^{16}$ Portanto, como instrumento de modificação de uma realidade desigual, "os direitos humanos devem prestar-se para aumentar nossa "potência" e nossa "capacidade" de atuar no mundo" (HERRERA FLORES, 2009a, p. 81).

${ }^{17}$ Herrera Flores complementa essa perspectiva destacando a necessidade de se buscar um caráter universalizável dos Direitos Humanos, que os possibilitem passar a ser vistos como um objetivo a ser alcançado através de um processo cultural de diálogo permanente - pautado em uma racionalidade de resistência - entre o $\mathrm{eu}$ e o outro, e não como algo pronto e acabado, pois "nossa visão complexa dos direitos humanos baseia-se em uma racionalidade de resistência. Uma racionalidade que não nega o que é possível chegar a uma síntese universal das diferentes opções relativas a direitos. (...). O que negamos é considerar o universal como um ponto de partida ou um campo de desencontros. Ao universal há que se chegar universalismo de chegada ou de confluência - depois (não antes de) um processo conflitivo, discursivo de diálogo (...). Falamos de entrecruzamento e não de mera superposição de propostas” (2002, p. 21).

${ }^{18}$ Sob essa perspectiva de utilização do discurso de direitos humanos para justificativa para quaisquer medidas entre países, ou entre o Estado e seu povo, ver ZIZEK, Slavoj. Contra os Direitos Humanos. Trad. por CAVALCANTE, Sávio. In.: Revista Mediações. V. 15. N. 1. Jan./jun. Londrina, 2010, p. 11-29.
} 
homogeneizado, onde a diversidade é encoberta para se alcançar uma identidade, uma estética do correto, já não é aceitável, haja vista ser mais um instrumento de exclusão e afastamento da grande maioria da humanidade, daquilo que é elementar para o mínimo de dignidade dos seres humanos.

Neste sentido, a busca deve ser por um universalismo de chegada, um modelo racional aos direitos humanos que não aceite mais uma visão microscópica da realidade sócio-política, econômica e cultural da atual conjuntara social em que a humanidade está inserida, uma racionalidade que parta de nós mesmos, visto aqui como a união indissolúvel do eu e de todos os outros que lhe existam.

A partir dessas premissas é preciso buscarmos novas concepções, diversas daquelas desenvolvidas pela modernidade europeia e, também, norte americana, uma busca que deve voltar os olhos para outras matrizes sociais, políticas, culturais, econômicas, que nos sirvam de impulso para abandonar todo tipo de visão que esteja fechada nos dogmas universalizantes da homogeneização moderna.

É aqui que surge o debate sobre o novo constitucionalismo latino-americano, uma perspectiva política, social, cultural, forjada no contexto latino-americano, e que pode surgir como um instrumento contra hegemônico, aos fundamentos hegemônicos das teorias inerentes ao Estado, às Constituições e, em especial, aos Direitos Humanos.

Por fim, a busca por uma concepção intercultural dos direitos humanos, seja a partir de mecanismos de cunho cultural, epistêmicos, políticos, sociais ou econômicos, é essencial, pois será através dela que se originarão energias nômades, migratórias, móbiles (HERRERA, 2002, p. 23), capazes de nos permitir deslocar pelos diferentes pontos de vista, sem a pretensão, ou o poder, de negar validade a qualquer deles, concretizando, assim, a possibilidade de luta pela dignidade, reconhecimento e respeito, à toda humanidade.

AS NOVAS TENDÊNCIAS CONSTITUCIONAIS LATINO-AMERICANAS: DA UNIDADE MONOCULTURAL À PLURALIDADE INTERCULTURAL DOS DIREITOS HUMANOS

\section{A Modernidade e o Constitucionalismo Latino-Americano - os fundamentos modernos e a exclusão constitucional da diversidade nos primórdios do constitucionalismo latino-americano}

Para visualizarmos as novas tendências constitucionais latino-americanas que vão conformando o que vem sendo chamado de novo constitucionalismo latino-americano, é vol.09, n. 03, Rio de Janeiro, 2016. pp. 
necessário realizarmos, assim como no início do capítulo acima, uma abordagem do início do pensamento moderno e, consequentemente, do início da racionalidade, ainda hoje, inerente ao Estado e às Constituições mundo afora, principalmente, nos países de seu lado ocidental.

Sobre o início da modernidade, como visto anteriormente, adotamos - em que pese não percebermos a história de forma linear, afinal, "a história não pode ser encerrada entre os muros de uma classificação" (HERRERA FLORES, 2009b, p.105), algo estanque a partir de datas e eventos históricos - a posição de Dussel, para quem a modernidade teve como início emblemático o ano de $1492^{19}$, tendo como principais marcos a "Conquista da América" e a queda de Granada, última grande cidade mulçumana (o outro, o diferente) da Europa, demarcando assim, o início do encobrimento desse diferente e a construção de uma identidade do Eu, a partir dos padrões civilizatórios do europeu.

Portanto, a construção da arena onde os direitos humanos se desenvolveram até a concepção universalizante, ainda hoje presente nos discursos políticos, midiáticos e acadêmicos, carrega consigo elementos que marcam uma concepção datada, com endereço e características próprias de um dado povo, ou seja, os elementos de formação do Ser moderno, a partir do modus vivendi europeu, impregnaram a concepção universal dos direitos humanos, perfazendo-a a partir de um aspecto eminentemente monocultural.

A matriz constitucional que nascerá com o fim das primeiras formas de Estados absolutistas $^{20}$, por exemplo, se pautará na busca por uma homogeneização social, política, econômica ainda maior, ou seja, é nesse contexto que o ideal da afirmação de uma identidade nacional capaz de conformar a ideia de um povo, de uma nação, nos fica mais claro, haja vista o fato de um dos pilares desse constitucionalismo da Modernidade ser a monoculturalidade.

Percebendo essa característica, principalmente em relação aos primeiros modelos constitucional-liberais dos Estados europeus, que nascem como os primeiros exemplos dos movimentos revolucionários da época, Santos (2009, p. 206) destaca que deles decorrerá - a partir da colonização da América Latina pelo conquistador e colonizador europeu - o fato de todos os Estados latino-americanos, que surgem posteriormente, nascerem a partir de uma

\footnotetext{
${ }^{19}$ Para melhores esclarecimentos, ver DUSSEL, Henrique. 1492 El Encubrimiento Del Otro: hacia El origen del "mito de La Modernidad. La Paz: Plural Editores, 1994.

${ }^{20}$ Pela limitação de espaço de um trabalho como este - um artigo científico - não serão analisadas as inflexões e distinções do surgimento e da maturação das matrizes constitucionais de fundamento romanogermânico e anglo-saxão no contexto europeu. Contudo, para melhores esclarecimentos acerca do surgimento e do desenvolvimento dessas matrizes constitucionais e de seus influxos na construção do constitucionalismo moderno de matiz nacional, ver LOSANO, Mario G. Os grandes sistemas jurídicos: introdução aos sistemas jurídicos europeus e extraeuropeus. Trad. por VAREJÃO, Marcela e rev. por LEITE, Silvana Cobucci. São Paulo: Martins Fontes, 2007, p. 31-61 e 320-335.
} 
homogeneização (monocultural) de diferentes e diversificadas culturas, fossem elas indígenas ou africanas, ou seja:

Os conceitos fundamentais do constitucionalismo moderno são, assim, os de soberania popular e homogeneidade do povo (é dizer que o povo é homogêneo). Quando se fundou as Nações Unidas, a grande maioria dos países latino-americanos declararam que não tinham minorias étnicas. (...). Tudo isso para criar um Estado que representasse uma nação e também uma cultura (tradução nossa).

Se a modernidade nasce e constrói seus primeiros modelos de Estados a partir da sobreposição de uma cultura sobre as demais, de uma vontade, de um querer, de uma forma de sociedade $^{21}$ - entendida como a única racionalmente possível - seu amadurecimento, sua continuidade, também carrega esses mesmos detalhes, de modo que a construção políticocultural ínsita aos direitos humanos, a partir de um universalismo de partida, hegemônico ${ }^{22}$, violenta a pluralidade da diversidade que deveria permear esse debate.

Assim, a busca por uma nova concepção racional, política, social, econômica e, sobretudo, cultural, aos Direitos Humanos, necessariamente, deverá passar pelo desencobrimento (libertação) dos conhecimentos, dos modos de vida, das perspectivas de ser, de estar e de ter, que foram encobertos ao longo dos séculos por aquilo que Dussel (1994) chamará de "mito da modernidade 23 ", o que será proposto aqui a partir, como passaremos a

\footnotetext{
${ }^{21}$ Neste sentido, Anderson (1995, p. 60-83) destaca como a formação do Estado Espanhol, no início da modernidade, pode ser visto como exemplo claro dessa sobreposição político, social e cultural, ou seja, em seu nascimento o Estado espanhol, ainda absolutista, surge de um movimento de ascensão de dois reinos (Castela e Aragão) - que se juntam pelo casamento de Isabel (castelhana) e Fernando (aragonês) - e sua sobreposição as demais cidades, reinos ou regiões próximas, tais como: Milão, Navarra, Catalunha, Valência, Galícia, Andaluzia.

${ }^{22}$ Ao acentuar a atual concepção hegemônica dos Direitos Humanos, Krohling destaca que essa "concepção de Direitos Humanos está inserida em um contexto de domínio cultural pelo fato de nem todas as tradições culturais terem atuado na formação dos instrumentos internacionais de Direitos Humanos” (2009, p. 91), pois a atual - e até hoje a única reconhecida como válida e correta - percepção que se tem sobre o que sejam, ou quais são, os Direitos Humanos, possui matiz ocidental e europeizada.

${ }^{23}$ A modernidade, enquanto momento de dominação e culturalização do Mundo a partir da racionalidade europeia dos conquistadores e colonizadores, sobretudo, das Américas e da África, pode ser vista como o período que desencadeou uma sobreposição de um modelo político, social, econômico e cultural, vindo da Europa, a todos os mais longínquos lugares e formas de organização social do planeta, promoveu o encobrimento de um pluralismo epistemológico, tão querido e necessário no contexto latino-americano atual, o que acabou legitimando todos os movimentos de violação à cultura, à diferença, à diversidade, movimentos estes que caracterizaram-se pelo cometimento de etnocídios (ALMEIDA, 2012, p. 72), de epistemicídios (SANTOS, 2011, p.87), verdadeiros, nas palavras de Wolkmer, genocídios étnico-culturais (2008, p. 183). Sobre essa perspectiva de dominação cultural, importantes, também, são as palavras de Herrera Flores para quem a "língua e a cultura, ou, em outros termos, a civilização foi o instrumento a partir do qual se disseminará por toda a orbe a verdade, a palavra, revelada misteriosamente pela hipotética e improvável vontade de nosso Deus, de nossa Razão, de nossa Lógica, de nossa forma de organizar o mundo, esquecendo, ou ocultando, a natureza básica da linguagem: facilitar a tradução e a interação intercultural" (2009b, p. 80).
} vol.09, nº. 03, Rio de Janeiro, 2016. pp. 
ver, dos contornos libertários inerentes a racionalidade que legitima os mais recentes movimentos constitucionais do $\mathrm{Sul}^{24}$ - América Latina.

Sobre os desvelamentos dessa nova construção constitucional, que se propõe emancipatória e libertária, e que conformará um novo paradigma de Estado (Plurinacional), Santos (2007) aponta para necessidade, existente em nosso tempo, de rediscutirmos o que pode, ou não, ser visto como padrão para as constituições, para o Estado e, sobretudo, para os direitos humanos, ou seja, está na hora de construirmos um debate novo, capaz de efetivar o resgate de uma parcela social - no contexto latino-americano - esquecida há aproximadamente 500 anos.

Essa necessidade, a partir de Santos (2007, p. 26-27), decorre de inúmeros fatores, sejam eles de cunho social, político, cultural ou econômico, de onde é possível retirar, um principal, que segundo ele, decorre do fato de hoje enfrentamos um grande distanciamento entre a teoria política e a prática política, ou seja, aquilo que os representantes do povo ${ }^{25}$ dizem ser a vontade geral, não vislumbra mais uma participação efetiva de todos, pois aos detentores do poder econômico é dada a capacidade de influenciar as diretrizes do Estado moderno, algo que a grande maioria de seu povo não possui.

É a partir daqui que podemos identificar as novas tendências constitucionais latinoamericanas, que buscam efetivar uma nova conotação à democracia moderna ao provocarem o que Santos (2007, p. 47) denominará de Demodiversidade, ou seja, a construção de uma democracia onde a diversidade cultural ${ }^{26}$ tenha voz e o poder necessário para se fazer presente

\footnotetext{
${ }^{24} \mathrm{O}$ novo constitucionalismo latino-americano, que emerge a partir dos movimentos e lutas sociais nas últimas décadas, cujos ciclos de formação debateu-se, perfunctoriamente, neste trabalho, objetiva promover um diálogo entre o Eu/Nós e os Eles/Outros, que se dará não por mecanismos de reconhecimento por aquilo que o Eles tem de igual ao Nós, mas por aquilo que o Eles tem em si, ou seja, por aquilo que lhes caracterizam enquanto diferentes, ou seja, enquanto pluralidade, diversidade cosmopolita, sua própria identidade cultural (DUSSEL, 2012, p. 17). Sobre esses ciclos de formação do novo constitucionalismo latino-americano é importante ressaltar as palavras de Wolkmer e Fagundes (2011, p. 403) para quem esse novo cenário foi construído em três momentos, ou seja, “(...) um primeiro ciclo social e descentralizador das Constituições Brasileira (1988) e Colombiana (1991). (...) um segundo ciclo (...) participativo popular e pluralista, em que a representação nuclear desse processo constitucional passa pela Constituição Venezuelana de 1999". E um terceiro ciclo - plurinacional comunitário - "passa a ser representado pelas recentes e vanguardistas Constituições do Equador (2008) e da Bolívia (2009)".

${ }^{25}$ A palavra povo é empregada em todo o trabalho com o significado mais amplo possível, ou seja, não se discute aqui - salvo quando o fizer expressamente - quem são as pessoas que formam esse povo. Para tal, ver MÜLLER, Friedrich. Quem é o Povo? a questão fundamental da democracia. São Paulo: Editora Max Limonad, 1998.

${ }^{26}$ Sobre essa busca por uma nova concepção - ou seja, por um novo sentido ao termo, agora a partir das premissas da interculturalidade - à democracia desencadeado no atual cenário constitucional latinoamericano, é importante destacar as palavras de Chivi Vargas sobre o surgimento, neste contexto, dessa perspectiva intercultural da democracia, que reconhece e possibilita uma manifestação política de forma heterogênea, pois "A democracia igualitária é a superação da democracia representativa do século XIX e da participativa do século XX, por uma democracia onde a igualdade material é o centro da atividade estatal, a vol.09, n. 03, Rio de Janeiro, 2016. pp. 1225 
nas arenas do debate político de seu povo, onde não ser igual é ser normal, e onde o diálogo ${ }^{27}$ possa ser efetivado sem a "pressa de uma decisão".

\section{As Novas Tendências Constitucionais Latino-Americanas - buscando fundamentos no sul global para iniciar um diálogo intercultural com o norte na busca pela refundação constitucional dos direitos humanos a partir da diversidade}

As tendências constitucionais das últimas três décadas que compreendem o que vem sendo chamado de novo constitucionalismo latino-americano, podem ser vistas como uma possível tentativa, a partir da insurgência do Sul Global, de se vencer os obstáculos à diversidade, pois nesse novo cenário constitucional latino-americano, que é pautado na transformação do Estado - e ao modo de percebermos os direitos e os deveres dos indivíduos, debate onde se inserem os direitos humanos.

Essa transformação se dará através, não só de uma política de reconhecimento, mas e, principalmente, a partir de um pluralismo epistemológico ${ }^{28}$, capaz de dar possibilidade ao debate, a nível constitucional, das discussões sobre aquilo que a Constituição do Equador de 2008 e da Bolívia de 2009, chamaram, cada qual a seu modo, de "bem viver (sumak kawsay) e dos direitos de pachamama" 29 .

igualdade formal se acha no baú da história hipócrita do constitucionalismo moderno" (2010, p. $34-$ tradução nossa).

${ }^{27}$ Esse modelo de discussão da democracia, pautada pelo diálogo é um processo que se desenvolve na sociedade e vai atingindo o seu exercício paulatinamente, de modo que as novas construções constitucionais Latino-Americanas ainda demorarão algum tempo para surtirem os efeitos pretendidos pelos novos textos constitucionais. Para se entender melhor os fatos que levaram vários países da América Latina reconstruir seus fundamentos constitucionais, principalmente em relação à democracia, buscando uma maior participação de indivíduos que por muito tempo não tiveram acesso às decisões tomadas por seus governos, ver TÁPIA, Luis. Pensando La Democracia Geopolíticamente. La Paz: Muela Del Diablo Editores, 2009. Cap. 4.

${ }^{28}$ Neste sentido, ver também SANTOS, Boaventura de Sousa. Para Além do Pensamento Abissal: das linhas globais a uma ecologia dos saberes. In: Revista Crítica de Ciências Sociais, n. 78, Outubro de 2007, p. 3-46; TAPIA, Luis. Tiempo, Poiesis y Modelos de Regularidad. In: Pluralismo Epistemológico. La Paz: Muela del Diablo Editores, 2009.

${ }^{29}$ Sobre essas premissas ínsitas ao novo constitucionalismo latino-americano, Céspedes (2010, p. 10) analisará a necessidade de resgatarmos o outro, o diverso, o diferente, encoberto pela hegemonia uniformizadora, homogeneizante e ideologizante da modernidade colonizadora, a fim de que alcancemos esse bem viver que, segundo ele, trata-se de "(...) recuperar a vivência de nossos povos, recuperar a cultura da vida e recuperar nossa vida em completa harmonia e respeito mútuo com a mãe natureza, com a Pachamama, onde tudo é Vida, onde todos somos uywas, criados da natureza e do cosmos, onde todos somos parte da natureza e não há nada separado, onde o vento, as estrelas, as plantas, as pedras (...) são nossos irmãos, onde a terra é vida em si, bem como o lugar de todos os seres vivos". Para maior aprofundamento ao temos destacados, impossibilitado no presente estudo pelos limites de um artigo, ver CÉSPEDES, David Choquehuanca. Hacia La Reconstrucción Del Vivir Bien. In.: Sumak Kawsay: recuperar el sentido de vida. ALAI, nº 452, año XXXIV, II época, Quito, Ecuador, febrero 2010 e MACAS, Luis. Sumak Kawsay: la vida en plenitud. In.: Sumak Kawsay: recuperar el sentido de vida. ALAI, $\mathrm{n}^{\circ}$ 452, año XXXIV, II época, vol.09, $\mathrm{n}^{\circ}$. 03, Rio de Janeiro, 2016. pp. 1226 
Sobre esse pluralismo epistemológico, León Olivé (2009, p. 25) acentua se tratar “de uma disciplina que analisa criticamente as práticas cognitivas, ou seja, aquelas, mediante as quais, se cria, se aplica e se avalia diferentes formas de conhecimento (...)".

Se quer, com essa perspectiva, portanto, vencer o tradicionalismo ínsito ao modelo político, econômico, cultural, constitucional e social do conquistador e colonizador europeu, ou seja, um modelo de constitucionalismo moderno, limitador das perspectivas inerentes aos direitos humanos, tais como: o diálogo em busca de um novo sistema constitucional, onde todos, sem encobrimento ou exclusões, possuam o poder necessário para participarem das decisões, sempre dialogadas, de seus Estados, de modo que as diversas culturas, muitas milenares, não sejam sobrepostas por aquilo que um determinado modo de ser tem por correto.

Sobre essa perspectiva, Herrera Flores (2003, p. 299) destaca que será necessário, para a alcançarmos, realizar aquilo que denomina como a racionalidade da resistência, cujo fim é a busca por uma construção dos Direitos Humanos que "abrace" todas as pessoas ínsitas ao contexto social em que vivemos, sejam elas representantes do eu/nós, ou do outro/eles ${ }^{30}$, pois:

A instauração paulatina de uma ordem global desigual e injusta está afetando não só o que vai restando de Estado do Bem-Estar - onde este existiu -, mas, o que é mais grave, a capacidade social e coletiva de propor alternativas baseadas na justiça social (HERRERA FLORES, 2009a, p. 175).

As novas tendências constitucionais latino-americanas, sobretudo a partir das duas últimas décadas, podem ser vistas como instrumentos de resistência, mecanismos a partir dos quais se objetiva romper com o modelo posto, a partir de baixo, promovendo uma transformação social através do debate aberto, franco e sem fim, com decisões provisórias, mas que não colocam um ponto final à questão.

\footnotetext{
Quito, Ecuador, febrero 2010. Contudo, importante destacar ainda, que esse bem viver do homem não pode estar dissociado dos direitos, segundo as bases do novo constitucionalismo latino-americano, da "mãe" terra, pois a partir da construção constitucional, por exemplo, do Equador em 2008, é possível percebermos que houve o reconhecimento de uma nova - frente à matriz moderna ocidental - percepção de que todos os seres fazem parte de um organismo vivo, chamado e conhecido pelas comunidades andinas, por signo de pachamama, que passa a ser vista, a partir de então, enquanto verdadeiro sujeito de direitos. Para a visualização dessas premissas na seara jurídica, ver a AÇÃO CONSTITUCIONAL DE PROTEÇÃO À NATUREZA, julgada em 30 de março de 2011, na Corte Provincial de Justiça de Loja, no Equador (Juicio 11121-2011-0010). Disponível em: 〈www.funcionjudicial-loja.gov.ec>. Acessado em 27 de Julho de 2015, por onde, a partir desta Ação Constitucional, um rio - rio Wilcabamba - figurou como polo ativo de uma demanda, ganhando-a em face do governo provincial de Loja, no Equador, por tê-lo praticado o depósito de materiais de escavação em seu leito, sem que fosse realizado, previamente, um estudo do impacto ambiental e social na área.

${ }^{30}$ Sobre esse ponto, o mesmo Herrera Flores aponta a necessidade de nos transformarmos durante a busca desse objetivo, ou seja, que "sejamos atrevidos e redefinamos o mundo valentemente, afirmando nossas diferenças e nossos valores, articulando as ilhotas de resistência que estão proliferando por todos os lados e construindo formas organizativas isentas de dominação hierárquica, mas sempre impulsionando a tendência à articulação e à cooperação" (2009b, p. 6).
} vol.09, nº. 03, Rio de Janeiro, 2016. pp. 
Portanto, uma das principais características desse cenário que surge, é o fato de que nesse novo constitucionalismo o povo é visto como uma sociedade aberta de sujeitos constituintes, o que, via de consequência, representa uma superação das noções de identidade nacional, construídas em torno de uma cultura hegemônica, verdadeira estética do correto, do certo, do belo, e que acabou sendo levada à concepção universal dos direitos humanos a partir das características do pensamento moderno.

Há a necessidade, neste sentido, de exercitar um resgate das várias formas de vida, de ser, de estar no mundo, a fim de que deste resgate do passado, seja possível trilhar um novo futuro, que não carregue mais o peso da indiferença, do preconceito, do colonialismo ${ }^{31}$ e da hegemonia ocidental moderna, ínsita ao conquistador e ao colonizador europeu a partir do final do séc. XV e início do séc. XVI.

Mas o novo constitucionalismo latino-americano, a partir de todas as pretensões, não nasce com o advento de uma única constituição, ou seja, não é fruto de uma elucubração teórico-filosófica de um dado momento, povo ou ser, pois enquanto historicidade, não pode ser visto como algo estanque, com data e hora para acontecer, de modo que sua compreensão deve se dar a partir do estudo de seus ciclos de formação, sob os quais há inúmeras perspectivas.

Desse modo, é importante frisar que para o presente estudo, optou-se, metodologicamente, pela visão dos ciclos de formação desse constitucionalismo da diversidade que emerge, segundo Raquel Zonia Yrigoyen Fajardo, para quem essas novas tendências constitucionais latino-americanas, são fruto de vários ciclos de debates, cada qual representado por vários textos constitucionais, de onde é possível destacar que:

O horizonte do constitucionalismo pluralista contemporâneo na América Latina passa por três ciclos: a) o constitucionalismo multicultural (1982 a 1988): composto pelas Constituições do Canadá de 1982, da Guatemala de 1985, Nicarágua de 1987 e do Brasil de 1988. A Constituição do Canadá teria inaugurado o multiculturalismo, pois abre um primeiro reconhecimento de sua herança multicultural e da incorporação dos direitos aborígines; b) o constitucionalismo pluricultural (1989 a 2005): inaugurado pelas Constituições da Colômbia de 1991, México de 1992, Perú de 1993, Bolívia de 1994, Argentina de 1994 e Venezuela de 1999; c) o constitucionalismo plurinacional (2006): inaugurado com o surgimento das Constituições do Equador de 2008 e da Bolívia de 2009 (2011, p. 139-184) $)^{32}$.

É possível perceber a partir de então, que todas as recentes construções constitucionais latino-americanas objetivaram, num primeiro instante, buscar uma melhor fundamentação e

\footnotetext{
${ }^{31}$ Esse colonialismo, conforme destaca Herrera Flores, “(...) foi e segue sendo uma das maiores violações à ideia de direitos humanos, pois coloca uns, os colonizadores, no papel de superiores e civilizados e outros, os colonizados, no papel de inferiores e bárbaros" (2009a, p. 32).

${ }^{32}$ Para melhor compreensão desses ciclos de formação do novo constitucionalismo latino americano a partir das premissas lançadas acima, ver BRANDÃO, Pedro. O Novo Constitucionalismo Pluralista Latino-
} Americano. Rio de Janeiro: Lumen Juris, 2015, cap. 1.2, p. 24-34. 
legitimação, necessárias à constituição de um modelo democrático para o Estado de Direito, sendo que, posteriormente, e em consequência dessa primeira busca, objetivaram verificar a efetividade dessas Constituições.

Esse novo constitucionalismo latino-americano, então, se constitui em uma teoria ${ }^{33}$ cujo objetivo é o avanço democrático da Constituição ${ }^{34}$, e consequentemente, do Estado, abrindo espaço para novas arenas de debate, bem como para novos atores sociais, fruto de uma libertação/emancipação de seu julgo político, social e cultural, dos últimos séculos.

A constitucionalização da diversidade, portanto, principalmente, através desses recentes movimentos constitucionais latino-americanos (o brasileiro, em 1988; o colombiano, em 1991, o venezuelano, em 1999; o equatoriano, em 1994, mas sobretudo em 2008 e, por fim, o boliviano, em 2009) ${ }^{35}$ nos demonstra como o outro, violado, encoberto, esquecido, pode ser capaz de passar a figurar como sujeito importante para as decisões do Estado, não somente com o depósito de seu voto para a escolha de representantes, mas como sujeito ativo, atuante, que deve e será ouvido no decorrer da história ${ }^{36}$, importante no momento de interculturalizarmos a concepção monocultural e universal dos direitos humanos.

Ao analisar o momento de surgimento do novo constitucionalismo latino-americano, importante análise é feita por Grijalva, ao apontar para um constitucionalismo plurinacional e libertário, embasado em relações interculturais, que rompem com as estruturas do moderno Estado nacional, ao reconhecer que:

\footnotetext{
${ }^{33}$ Sobre esse novo constitucionalismo latino-americano representar, ou não, uma corrente doutrinária, teórica, possível, Viciano Pastor e Martínez Dalmáu escrevem sobre essa dúvida, chegando à conclusão de que esse novo constitucionalismo latino-americano é uma teoria democrática da constituição, que poderá "romper com o que se considera dado e imutável, e que poderá avançar pelo caminho da justiça social, da igualdade e do bem-estar dos cidadãos" da América Latina (2013, p. 5)

${ }^{34}$ Isso é percebido a partir do momento em que o conteúdo dessas novas Constituições, forjadas sob os auspícios latino-americanos de agora, expressar a vontade de seu povo, que lhe é soberana (PASTOR e DALMÁU, 2010, p. 18 e 19).

${ }^{35}$ Em decorrência da necessidade de limitação do debate ao problema de pesquisa exposto acima, a análise dos referidos textos constitucionais se deu de forma perfunctória, ou seja, buscou-se tracejar aspectos gerais que demonstram como os movimentos constitucionais latino-americanos das últimas décadas pode ser visto como uma ruptura com o padrão moderno do constitucionalismo nacional, sobretudo o liberal ou neoliberal, dos últimos séculos. Contudo, ressaltamos que já analisamos, num espaço adequado, os desdobramentos dos mais recentes textos constitucionais sul-americanos (venezuelano de 1999, equatoriano de 2008 e boliviano de 2009), analisando inúmeros aspectos dessas cartas constitucionais que podem desdobrá-las em marcos desse novo cenário constitucional latino-americano, para tanto ver. SILVA, Heleno Florindo da. Teoria do Estado Plurinacional - o novo constitucionalismo latino-americano e os direitos humanos. Curitiba: Editora Juruá, 2014. Cap. 2.3, p. 130-146.

${ }^{36}$ Nesse sentido, é possível percebermos que o novo constitucionalismo latino-americano advém desse objetivo - uma reformulação de conceitos formados na modernidade, tal como a ideia de democracia representativa - que aparece estampado nos textos constitucionais mais recentes do continente, qual seja: o de legitimar, bem como, expandir a democracia, surgindo ao contexto constitucional como resultado de lutas e de reivindicações populares por um novo modelo de organização do Estado e do direito (MORAES e FREITAS, 2013, p. 106 e 107), que acabará, via de consequência, nos dando o cabedal necessário para a reformulação de uma perspectiva intercultural dos direitos humanos.
} vol.09, nº. 03, Rio de Janeiro, 2016. pp. 
O constitucionalismo plurinacional é ou deve ser um novo tipo de constitucionalismo baseado em relações interculturais igualitárias que redefinem e reinterpretam os direitos constitucionais e reestruturam a institucionalidade provenientes do Estado Nacional. O Estado plurinacional não é ou não deve se reduzir a uma Constituição que inclui um reconhecimento puramente cultural, (...), senão um sistema de foros de deliberação intercultural autenticamente democrática ${ }^{37}(2008$, p. 50-51 tradução nossa).

$\mathrm{O}$ constitucionalismo que se pretende e se defende a partir dessa perspectiva latinoamericana que surge, portanto, nos permite superar as leituras liberais, procedimentais ou instrumentais da modernidade, abrindo espaço para que, conforme visto, a democracia não se restrinja a um devaneio social de um momento de luta contra os monopólios burgueses, ou contra a falta de concretização dos direitos fundamentais ou, ainda, contra as restrições impostas pela cultura globalizante do capital (LINERA, 2010, p. 11-24).

Nascido na América Latina, sobretudo a partir das culturas andinas, as novas tendências constitucionais latino-americanas, trabalham no sentido de recuperar a origem revolucionária das discussões constitucionalistas, reconstruindo suas percepções a partir de uma busca pela emancipação/libertação social de todos aqueles que foram excluídos pelo conquistador e colonizador moderno, possibilitando-os participar ativamente da construção constitucional de seu país ${ }^{38}$, ou seja:

A evolução constitucional responde ao problema da necessidade. As grandes mudanças constitucionais se relacionam diretamente com as necessidades da sociedade, com suas circunstâncias culturais, e do grau de percepção que estas sociedades possuem sobre as possibilidades de mudança de suas condições de vida que, em geral, na América Latina não cumprem com as expectativas esperadas nos dias de hoje (DALMÁU, 2008, p. 22 - tradução nossa).

As discussões trazidas nos contextos de formação do novo constitucionalismo latinoamericano, se constituem numa tentativa de ruptura com o modelo racional moderno constitucional de matriz, sobretudo, europeia, de cunho nacionalizante e universalizante,

\footnotetext{
${ }^{37}$ A partir dessas premissas, Grijalva destacará como deveremos nos pautar na condução desse novo modelo constitucional latino-americano, chegando à conclusão de que nesse paradigma, necessariamente, deveremos ser: Dialógicos - pois o novo modelo requer comunicação e deliberações permanentes entre as culturas; Concretizantes - pois deveremos buscar soluções específicas, e em tempo, para situações individuais e coletivas; e Garantistas - haja vista essas soluções surgirem por meio de deliberações, cujo marco de compreensão é o reconhecimento dos valores constitucionais institucionalizados pelos Direitos Humanos (2008, p. 52 - tradução nossa), mas não a partir de uma concepção universalizante desses direitos, mas, de outro lado, a partir de sua observação como produtos a serem construídos interculturalmente.

${ }^{38}$ Quer-se uma Constituição reflexo direto do poder constituinte - que agora tem a participação, a voz e a palavra dos excluídos - o que, via de consequência, servirá para percebê-la como fundamento último do poder constituído, e não o contrário. Portanto, uma das principais apostas desse novo constitucionalismo latino-americano vem a ser a "busca por instrumentos que recomponham a perdida (e nunca alcançada) relação entre a soberania e o governo. É o que a Constituição da Colômbia de 1991 denomina de 'formas de participação democrática', no Equador de 1998 se denomina governo participativo, na Venezuela e Bolívia recebe o nome de democracia participativa, e no Equador em 2008, participação na democracia" (PASTOR e DALMÁU, 2013, p. 4 e 20 - tradução nossa).
} vol.09, n. 03, Rio de Janeiro, 2016. pp. 
inerentes ao Estado, a Constituição e aos direitos humanos, daí decorrentes, no momento em que estabelece, dentre outras temáticas, que a unidade normativa de uma Constituição ${ }^{39}$, não necessariamente, representará uma uniformização social, política e cultural em torno de um modus vivendi hegemônico (SANTOS, 2010, p. 89).

É de um cenário como esse que Herrera Flores proporá um conceito crítico aos Direitos Humanos, partindo do ponto de vista de que esses direitos são frutos de uma convenção terminológica e político-jurídica, o que nos possibilitará construir um processo cívico cuja relação - político, cultural, social e econômica - se dê de forma a aumentar as potencialidades humanas frente à relação entre o Eu - homogeneizado e universalizado - e o Outro - inferior, selvagem, periférico, subalterno, excluído, matável - de modo que acaba por defini-los como

O conjunto de processos sociais, econômicos, normativos, políticos e culturais que abrem e consolidam - desde o 'reconhecimento', a 'transferência de poder' e a 'mediação jurídica' - espaços de luta pela particular concepção de Dignidade Humana (2010, p. 98-99 - tradução nossa).

A racionalidade por traz da concepção de direitos humanos desenvolvida aqui a partir dessa perspectiva crítica, portanto, se consubstancia da premissa de que tais direitos são frutos de processos sócio-político-culturais ${ }^{40}$ demonstrados em lutas históricas de resistência, em que uma parcela social, inferiorizada por uma dada hegemonia, busca reaver e confirmar suas visões particulares sobre, entre outras coisas, a dignidade humana.

Mas essa visão crítica e emancipadora, libertadora, dos direitos humanos não é o que hegemonicamente se desenvolveu durante os séculos, pois é possível perceber que as discussões acerca desses direitos surgiram ao longo da história humana com um caráter universalizante, hegemônico, seja por estarem subsumidos na razão ocidental da doutrina liberal-cristã, europeia-norte americana, seja por serem imanentes aos seres humanos como condição para o reconhecimento de sua humanidade.

Os direitos humanos, diante dessa visão crítica, assim como os demais instrumentos de dominação de um padrão cultural sobre as demais culturas, possuem, portanto, as mesmas

\footnotetext{
${ }^{39}$ Analisando a uniformidade do direito de matriz moderna, nacional e europeia, à luz das recentes constituições latino-americanas que trazem a possibilidade de um pluralismo jurídico, emancipatório, transformador e libertário, Santos destaca que "depois de dois séculos de suposta uniformidade jurídica não será fácil para os cidadãos, organizações sociais, atores políticos, servidores públicos, advogados e juízes adotarem um conceito mais amplo de direito que, ao reconhecer a pluralidade de ordenamentos jurídicos, nos permite desconectar parcialmente o direito do Estado e o (re)conectar com a vida e a cultura dos povos" (2009, p. 197 - tradução nossa).

${ }^{40}$ É importante destacar, neste ponto, que, mesmo que percebamos os Direitos Humanos como processos culturais, não percebemos a cultura como algo pronto e acabado, pois "nenhuma cultura é propriedade exclusiva de um grupo étnico, e nenhum grupo étnico possui uma cultura isenta de ambiguidade e interpretações plurais (...)" (MAİZ, 2012, p.42), ou seja, todas as culturas são incompletas (SANTOS, 2010, p. 446).
} vol.09, nº. 03, Rio de Janeiro, 2016. pp. 
características - trabalhadas até então - inerentes à modernidade. Sobre tais pontos, Dussel (1994, p. 80) aponta para o fato de que essa modernidade buscou sempre justificar a violência por detrás de seus atos, a ponto de universalizar uma dada concepção de direitos humanos.

A ideia de interculturalismo, neste sentido, deve ir mais além daquilo que Maíz (2012, p. 36) chama de sentido amplo ${ }^{41}$ - aqui visto como tradicional (HERRERA FLORES, 2009a, p. 153-155) -, ou seja, não pode se restringir a um conjunto de políticas institucionais de reconhecimento coletivo da diversidade, haja vista essa perspectiva absolutizar as identidades sociais, culturais e políticas de um modelo segregador, onde o reconhecido, mesmo reconhecido, não terá o mesmo valor do dominante.

De modo que esse pretenso interculturalismo deve ir além de um simples e não eficaz reconhecimento das diferenças. Deve ser um instrumento crítico, ou como denomina Herrera Flores, um pilar de resistência (2009a, p. 164), de libertação, de emancipação transformadora do Ser, pois:

(...) ao mesmo tempo em que rechaçamos os essencialismos universalistas e particularistas, damos forma ao único essencialismo válido para uma visão complexa do real: aquele que cria condições para o desenvolvimento das potencialidades humanas (...), que se componha não de imposições ou exclusões, mas sim de generalidades compartilhadas às quais chegamos, não das quais partimos.

Ou seja, é necessário darmos origem ao debate de uma reformulação intercultural dos direitos humanos, que nos possibilite percebe-los um projeto de universalização; como algo a ser construído e que no fim, e não no início, poderá ser universal, pois há, antes desse fato, a necessidade de resgatarmos os excluídos, os marginalizados, os selvagens aculturados, assim definidos pela racionalidade moderno-ocidental-cristã, imposta pelo colonizador, aos Direitos Humanos destacados na Declaração Universal dos Direitos Humanos de $1948^{42}$.

Além de um resgate do valor do outro, deverá ocorrer, para a assunção intercultural dos direitos humanos, um diálogo ${ }^{43}$ intercultural entre os diferentes. Um diálogo que perceba a

\footnotetext{
${ }^{41} \mathrm{O}$ signo, portanto, interculturalismo é percebido neste trabalho, para além de suas tradicionais definições, que o veem como o reconhecimento da existência de uma série de diferentes culturas dentro de uma mesma sociedade (KROHLING, 2009, p. 105), de modo que percebê-lo como um interculturalismo crítico, emancipador, libertário, de resistência, que não se paute em apenas reconhecer a diversidade, mais que, a partir dela, busque a transformação da realidade atual, altamente desigual, fruto de uma modernidade ocidental uniformizante e homogeneizante.

${ }^{42}$ Não se quer aqui deslegitimar a importância histórica deste documento internacional para as discussões sobre os Direitos Humanos, mas, assim como em relação às teorias do contrato social, essa Declaração é importante, tanto pelo que foi, é e diz, quanto pelo que silenciou e ainda silencia. Neste sentido, “(...) a Declaração Universal constitui, ainda hoje, um marco muito importante na luta pelo processo de humanização da humanidade. Porém, não podemos ocultar que seus fundamentos ideológicos e filosóficos quer dizer, culturais - são puramente ocidentais" (HERRERA FLORES, 2009a, p. 42).

${ }^{43}$ Para Krohling esse diálogo “(...) não se destina a afirmar dois opostos a fazer um dueto de duas vozes dissonantes ou o confronto de dois logoi, mas estabelecer um encontro ou um dia-logos, um elo dos logotipos, para atingir uma verdade que transcende" (2009, p. 84), ou seja, um diálogo que não exclua, mas vol.09, $\mathrm{n}^{\circ}$. 03, Rio de Janeiro, 2016. pp. 1232
} 
realidade desigual existente - e que contradiz a mencionada declaração de direitos acima (Herrera Flores, 2009a, p. 58 e 59) - mas que se estabeleça a partir de uma ideia comum, mesmo que cada interlocutor a veja por uma janela (KROHLING, 2009, p. 85) diferente.

Nesse sentido, o novo constitucionalismo latino-americano, como fruto de uma insurgência, uma construção que vem de baixo, dos excluídos, pode ser visto como um importante caminho para a assunção intercultural de um universalismo de chegada, pois segundo Herrera Flores “(...) são as ações sociais de baixo as que podem nos situar no caminho da emancipação em relação aos valores e aos processos de divisão do fazer humano hegemônico" (2009a, p. 24).

Essas lutas de baixo ${ }^{44}$ também são trabalhadas por Santos a partir de uma análise que as reconheça como espécies de um cosmopolitismo subalterno insurgente, que segundo ele, consistira na resistência "organizada contra os localismos globalizados e os globalismos localizados" (2011, p. 439).

Os movimentos sociais, políticos, econômicos e culturais que deram origem ao que hoje se denomina novo constitucionalismo latino-americano (um constitucionalismo sem pais) são exemplos dessas ações subalternas que insurgem ao momento atual de crise civilizatória, desdobramento de um modelo de globalização neoliberal, pautada num capitalismo de mercado, como fontes de crítica, de discussão e de rompimento com essa racionalidade.

Por fim, a partir dessas premissas nos é possível perceber, com o advento dessas novas tendências constitucionais latino-americano, importantes mecanismos de resgate dos excluídos, capazes de empoderá-los dos instrumentos necessários para a concretização de seu reconhecimento e da proteção de sua, plural e diversa, identidade, o que, via de consequência, acaba nos possibilitando, interculturalmente, rever nossa concepção - moderna, ocidental, europeia e universal - dos direitos humanos ${ }^{45}$.

inclua a diversidade, que transcenda a importância dos Direitos Humanos que vão surgindo como seus resultados, a partir da ideia material e concreta de dignidade humana, de um bem viver.

${ }^{44} \mathrm{O}$ outro exemplo dessas ações que vem de baixo, pode ser visto a partir das discussões propostas no Fórum Social Mundial, cuja meta principal é "consolidar uma globalização solidária que, como uma nova etapa da história do mundo, respeite os direitos humanos (...), a todos os cidadãos e cidadãs de todas as nações e ao meio ambiente, apoiando-se em sistemas e instituições internacionais democráticos que estejam a serviço da justiça social, da igualdade e da soberania dos povos" (HERRERA FLORES, 2009a, p. 102).

${ }^{45}$ Exemplos desse processo de empoderamento do outro, do diverso, ínsito ao novo constitucionalismo democrático latino-americano estão, dentre inúmeros outros aspectos, já no art. $2^{\circ}$ da Constituição Boliviana de 2009, que determina que os povos indígenas e campesinos terão reconhecimento ao domínio ancestral sobre seus territórios, ou seja "Dada a existência pré-colonial das nações e povos indígenas originários campesinos e seu domínio ancestral sobre seus territórios, se garantirá sua livre determinação frente ao Estado, que consiste em seu direito a autonomia, ao autogoverno, a sua cultura, e ao reconhecimento e consolidação de suas instituições e entidades territoriais, conforme a Constituição" (tradução nossa). E mais, a efetivação de instrumentos de participação popular na condução do Estado, como no texto venezuelano de 1999, que em seu art. $6^{\circ}$, dispõe que: "O Governo da República Bolivariana da Venezuela e das entidades vol.09, nº. 03, Rio de Janeiro, 2016. pp. 1233 


\section{INCONCLUSIVAS CONCLUSÕES - INICIANDO NOVOS DEBATES}

Após debatermos o caráter monocutural dos direitos humanos a partir de sua matriz moderno-ocidental, ínsita às características impostas pela conquista e pela colonização de sociedades, tais com as latino-americanas, periféricas, bem como de analisarmos, de um lado, a construção de um sentido universalizante a esses direitos a partir, sobretudo, do pós $2^{\mathrm{a}}$ Guerra Mundial, e a necessidade de rompermos, através de uma perspectiva intercultural, com esse universalismo, e de outro, os mecanismos e as novas possibilidades teórico-filosóficas e racionais advindas a partir de um conjunto de recentes construções constitucionais latinoamericanas, hoje conhecidas como novo constitucionalismo latino-americano, é chegado o momento de identificarmos um resposta, sempre provisória, ao problema lançado acima, mesmo que já tenhamos efetivado sua análise no decorrer de todo o trabalho.

Assim, é possível percebermos que as premissas desenvolvidas a partir da análise do que se convencionou chamar de novo constitucionalismo latino-americano carregam instrumentos de emancipação, ou seja, de libertação da parcela social de indivíduos que o sistema global atual, neoliberal, consumista e de mercado, fruto de um desenvolvimento do modelo econômico pautado nas linhas gerais do capitalismo, podendo serem vistas como

políticas que a compõem sempre será democrático, participativo, eletivo, descentralizado, alternativo, responsável e pluralista, com mandatos revogáveis". (Tradução nossa). Já o art. 70, da mesma carta constitucional, determina que: "São meios de participação e envolvimento das pessoas no exercício de sua soberania, na esfera política: a eleição de funcionários públicos, o referendo, o plebiscito, a revogação do mandato, as iniciativas legislativa, constitucional e constituinte e a assembleia de cidadãos, cujas decisões são vinculativas (...)" (tradução nosso). Por fim, Segundo Wolkmer (2013, p. 32) "este Poder Cidadão é exercido por um Conselho Moral Republicano (arts. 273 e 274), que é eleito e constituído pela Defensoria Pública, Ministério Público e Controladoria Geral da República. Dentre suas inúmeras responsabilidades, está a de estimular a observância e o respeito aos Direitos Humanos (art. 278)". De outro lado, a Constituição do Equador de 2008, dentre outros aspectos, determina em seu art. 275 que o regime de desenvolvimento nacional do Equador, será efetivado com vistas a garantir o bem viver intrínseco a ideia do Sumak Kawsay indígena e campesino, ou seja, “(...) o bem viver requererá que as pessoas, comunidades, povos e nacionalidades gozem efetivamente de seus direitos, e exerçam responsabilidades no marco da interculturalidade, do respeito a suas diversidades, e da convivência harmônica com a natureza". Assim, o art. 318, da mesma Constituição de 2008, garante o direito à água como um patrimônio nacional estratégico de uso público ou comunitário, não sendo admitidas - em relação ao direito à água -, dentre outras coisas, sua privatização. Por fim, a Constituição da Bolívia de 2009 determina que o Estado boliviano será organizado a partir de autonomias (...) departamental: arts. 277-279; regional: arts. 280-282; municipal: arts. 283 e 284; indígena originária campesina: arts. 289-297 (2013, p. 37) - criadas nesse modelo de Estado que é - segundo Wolkmer (2013, p. 37) - comunitário e plurinacional -, bem como, determina a existência de um pluralismo jurídico como uma grande inovação de seu Poder Judiciário, o que se dá a partir de um igualitarismo jurisdicional, pois tal poder será exercido por jurisdições que não se sobrepõem (art. 189, I e II, da CB/09) - a justiça comum e a justiça indígena, originária e campesina -, sendo que essa última, nos termos dos arts. 190, I, e 191, I, da CB/09, será exercida por suas autoridades, aplicando e respeitando-se seus princípios e valores culturais, normas e procedimentos próprios. Por fim, a referida Constituição determina que haverá, também, um Tribunal Constitucional Plurinacional para a salvaguarda da Constituição Boliviana de 2009, bem como solução dos conflitos entre as jurisdições comum e indígena, cujos membros serão eleitos mediante sufrágio universal (art. 198, da CB/09). 
capazes de transformar o sentido universal, homogeneizante e uniformizante, dos direitos humanos.

Seja em decorrência do reconhecimento e efetivação do empoderamento aos excluídos a partir do que se percebeu como pluralismo epistemológico, discutido desde uma racionalidade indígena-campesina, seja por abrir espaço, na arena das decisões político-sociais para a efetiva participação popular, remodelando os sistemas democráticos de representação política, que efetivaram um afastamento do poder, de todos aqueles que não cumpriam com determinadas características sociais, econômicas ou culturais, o novo constitucionalismo latino-americano, portanto, pode ser visto como um cenário onde as transformações parecem florescer das lutas sociais e políticas, inerentes a sua construção.

Por uma construção intercultural dos direitos humanos, capaz de romper com o um universalismo de partida, bem como capaz de promover uma percepção de um universalismo de chegada, a teoria crítica dos direitos humanos, desenvolvida aqui a partir de Joaquim Herrera Flores, atrelada a racionalidade libertária e emancipatória inerente às tendências constitucionais mais recentes na América Latina, podem nos servir como instrumentos contra hegemônicos, insurgentes e que, construídos a partir do Sul global, podem ser capazes de transformar a realidade civilizatória, hoje em crise, de nossas relações políticas, sociais, culturais e, sobretudo, econômicas.

Buscar a interculturalidade como modelo de racionalização dos direitos humanos é promover uma transformação de sentidos na busca de efetivar o resgate, a emancipação e a libertação da periferia, construída à sombra de um mercado local euro-norte americano, que fora globalizado como ferramenta de levar o desenvolvimento e os padrões de civilização à barbárie existente, sobretudo, a baixo da linha do equador, possuindo, neste ponto, o novo constitucionalismo latino-americano, enquanto construção de resistência, periférica, a necessidade de um olhar mais acurado, que nos afaste de homogeneizações e uniformizações que acabam por encobrir tais movimentos, a partir de alcunhas como a expressão bolivarianismo.

O respeito, a diversidade, o pluralismo, a plurinacionalidade, a emancipação e a libertação de todos os excluídos, dos encobertos e dos violentados em sua cultura, em seus saberes, em seu modo de vida, a partir da busca pelo bem viver, pautada no entendimento de que todos nós pertencemos a algo maior, que vive a partir de cada um de nós, é perceber que os direitos humanos ainda não são universais, pois não foram construídos universalmente, de modo que para rompermos com esse problema devemos expandir a arena de seu debate para 
além das amarras da modernidade, de modo que o novo constitucionalismo latino-americano nos pode ser útil nessa grande, difícil, árdua, mas necessária empreitada.

\title{
THE INTERCULTURALITY OF HUMAN RIGHTS AND THE NEW LATIN AMERICAN CONSTITUTIONALISM - FROM UNIVERSALISM OF DEPARTURE TO UNIVERSALISM OF ARRIVAL
}

\begin{abstract}
The new Latin American constitutionalism arises from a set of new ínsitas constitutional trends in Latin America, especially from the last three decades, is tracing it from a new perspective political, social, economic and cultural, able to fix important tools for liberation and emancipation, necessary to transform reality the vast majority of Latin Americans who still live on the margins of political society of their states. It is from this perspective that this study will analyze the mono-cultural aspect of human rights inherent in its universalizing rationality, as constructed during training, especially the constitutional States, and in particular after the end of World War II, with the Universal Declaration of Human Rights, aimed at launching a debate on the need for a reconfiguration from an intercultural rationality of liberation and emancipation of all those who, unlike the modern I do not yet have the means to use, universally, a minimum of dignity.
\end{abstract}

Keywords: Human Rights; universalization; New Latin American Constitutionalism; Interculturalism.

\section{REFERENCIAS}

ALMEIDA, Lúcio Flávio Rodrigues de. Lutas sociais e questões nacionais na América Latina: algumas reflexões. Disponível em: <http://www.pucsp. br/neils/downloads/v17_18_lucio.pdf >. Acessado em: 20 de Agosto de 2015.

ANDERSON, Perry. Linhagens do Estado Absolutista. $3^{\mathrm{a} e d .}$ trad. por BASTOS, Suely e BRITTO, Paulo Henrique. Tatuapé: Editora Brasiliense, 1995.

BRANDÃO, Pedro. O Novo Constitucionalismo Pluralista Latino-Americano. Rio de Janeiro: Lumen Juris, 2015.

CÉSPEDES, David Choquehuanca. Hacia La Reconstrucción Del Vivir Bien. In.: Sumak Kawsay: recuperar el sentido de vida. ALAI, $n^{\circ}$ 452, año XXXIV, II época, Quito, Ecuador, febrero 2010.

CHIVI VARGAS, Idón M. Nueva Constitución y Desarrollo Normativo. In.: Agência Latinoamericana de Información América en Movimiento. Ano 2010. Disponível em: $<$ http://alainet.org/active/35872\&lang=es>. Acesso em: 16 de Agosto de 2015. 
Os Caminhos da Descolonização na América Latina: os povos indígenas e o igualitarismo jurisdicional na Bolívia. In.: VERDUM, Ricardo (org.). Povos Indígenas: constituições e reformas políticas na América Latina. Brasília: IES, 2009. p. 45-67.

COMPARATO, Fábio Conder. A Afirmação Histórica dos Direitos Humanos. $8^{\mathrm{a}}$ ed. São Paulo: Saraiva, 2013.

DALMÁU, Rubén Martínez. El Nuevo Constitucionalismo Latinoamericano y el Proyecto de Constitución del Ecuador de 2008. In.: Alter Justicia: estudios sobre teoría y justicia constitucional. Ano 2, n. 1, p. 13-28, oct. 2008.

DUSSEL, Henrique. 1492 El Encubrimiento Del Otro: hacia El origen del "mito de La Modernidad. La Paz: Plural Editores, 1994.

Ética da libertação: na idade da globalização e da exclusão. $4^{\mathrm{a} e d .}$ Petrópolis: Editora Vozes, 2012.

FABRIZ, Daury Cesar. A Estética do Direito. Belo Horizonte: Del Rey, 1999.

GRIJALVA, Agustín. El Estado Plurinacional e Intercultural em La Constitución Ecuatoriana del 2008. In. Ecuador Debate 75. Quito-Ecuador, dezembro de 2008. p. 49-62. Disponível em: <http://www.ecuadordebate.com/wp-content/uploads/2010/06/ Ecuadordebate-75.pdf $>$. Acessado em: 17 de julho de 2015.

HERKENHOFF, João Batista. Curso de Direitos Humanos - gênese dos direitos humanos. Vol. 1. São Paulo: Editora Acadêmica, 1994.

HERRERA FLORES, Joaquín. Human Rights, Interculturality and Resistance Rationality.trad. por PRONER, Carol. In: Revista Direito e Democracia. Vol. 4. N. 2. $2^{\circ}$ Semestre de 2003. p. 287 a 304.

A (re) Invenção dos Direitos Humanos. Florianópolis: Fundação Boiteux, 2009a.

Teoria crítica dos direitos humanos: os direitos humanos como produtos culturais. Rio de Janeiro: Lumen Juris, 2009b.

Direitos Humanos, Interculturalidade e Racionalidade de Resistência. Trad. por PRONER, Carol. In.: Revista Sequência. Vol. 23. N. 44. Ano 2002. p. 9-30.

La Construcción de Las Garantías: hacia uma concepción antipatriarcal de la libertad y la igualdad. In.: SARMENTO, Daniel e outros (Coord.). Igualdade, Diferença e Direitos humanos. Rio de Janeiro, Lumen Juris, 2008.

Los Derechos Humanos em el Contexto de la Globalización: tres precisiones conceptuales. In.: RÚBIO, David Sanchez e outros. Direitos Humanos e Globalização anuário ibero-americano de direitos humanos (2003/2004). $2^{\mathrm{a}} \mathrm{ed}$. Porto Alegre: EDIPUCRS, 2010 .

KROHLING, Aloísio. A Ética da Alteridade e da Responsabilidade. Curitiba: Juruá, 2011.

Direitos Humanos Fundamentais: diálogo intercultural e democracia. São Paulo: Paulus, 2009.

Dialética e Direitos Humanos - múltiplo dialético: da Grécia à Contemporaneidade. Curitiba: Juruá Editora, 2014.

LAFER, Celso. A Internacionalização dos Direitos Humanos. Barueri: Manole, 2005. p. 3639. 
LINEIRA, Álvaro Garcia. El Estado en Transición: bloque de poder y punto de bifurcación. In.: LINERA, Álvaro Garcia e outros. El Estado: campo de lucha. La Paz: Muela Del Diablo Editores, 2010.

A Potência Plebeia: ação coletiva e identidades indígenas, operárias e populares na Bolívia. São Paulo: Boitempo, 2010a.

LOSANO, Mario G. Os grandes sistemas jurídicos: introdução aos sistemas jurídicos europeus e extraeuropeus. Trad. por VAREJÃO, Marcela e rev. por LEITE, Silvana Cobucci. São Paulo: Martins Fontes, 2007.

MACAS, Luis. Sumak Kawsay: la vida en plenitud. In.: Sumak Kawsay: recuperar el sentido de vida. ALAI, $n^{\circ}$ 452, año XXXIV, II época, Quito, Ecuador, febrero 2010.

MAÍZ, Ramón. Nacionalismo y Multiculturalismo. Disponível em <http://red.pucp.edu.pe/ridei/wp-content/uploads/biblioteca/081116.pdf >. Acessado em: 17 de agosto de 2015.

MORAES, Germana de Oliveira e FREITAS, Raquel Coelho. O Novo Constitucionalismo Latino-Americano e o Giro Ecocêntrico da Constituição do Equador de 2008: os direitos de pachamama e o bem viver (sumak kawsay). In: MELO, Milena Petters e WOLKMER, Antonio Carlos (orgs.). Constitucionalismo Latino-Americano: tendências contemporâneas. Curitiba: Juruá, 2013.

MÜLLER, Friedrich. Quem é o Povo? A questão fundamental da democracia. São Paulo: Editora Max Limonad, 1998.

OLIVÉ, León. Por una Auténtica Interculturalidad Basada em El Reconocimiento de La Pluralidad Epistemológica. In.: Pluralismo Epistemológico. La Paz: Mueladel Diablo Editores, 2009.

e OUTROS. Prólogo. In.: Pluralismo Epistemológico. La Paz: Mueladel Diablo Editores, 2009a.

PASTOR, Roberto Viciano e MARTÍNEZ DALMAU, Rubén. Aspectos Generales Del Nuevo Constitucionalismo Latinoamericano. In.: El Nuevo Constitucionalismo en América Latina: memorias del encuentro internacional el nuevo constitucionalismo (desafios y retos para el siglo XXI). Quito: Corte Constitucional Del Ecuador, 2010. p. 9-44.

Se Puede Hablar de un Nuevo Constitucionalismo Latinoamericano como Corriente Doctrinal Sistematizada? Disponível em: <http://www. juridicas.unam.mx/wccl/ponencias/13/245.pdf>. Acessado em 01 de agosto de 2013.

Necessidad y Oportunidad en el Proyecto Venezolano de Reforma Constitucional (2007). In.: Revista Venezolana de Economía y Ciencias Sociales.vol. 14, n. 2, 2008, p. $102-$ 132.

PIOVESAN, Flávia. Direitos Humanos e o Direito Constitucional Internacional. $13^{\mathrm{a}} \mathrm{ed}$. Rev. e Atual. São Paulo: Saraiva, 2012.

SANTOS, André Leonardo Copetti e LUCAS, Doglas Cesar. A Importância da Teorização sobre a Diferença para o Campo Jurídico. Uma Trilha nos Pensamentos de Nietzsche, Derrida, Foucault e Lyotard. In.: DEL'OLMA, Florisbal de Souza e OUTROS (orgs.) Multiculturalidade e cidadania: olhares transversais. Campinas/SP: Millennium Editora, 2015. 
SANTOS, Boaventura de Sousa. Para Além do Pensamento Abissal: das linhas globais a uma ecologia dos saberes. In: Revista Crítica de Ciências Sociais, n. 78, outubro de 2007, p. 3-46.

A Gramática do Tempo: para uma nova cultura política. $3^{\mathrm{a}}$ ed. São Paulo: Cortez Editora, 2011.

Refundación del Estado en América Latina: perspectivas desde una epistemología del sur. Buenos Aires: Antropofagia, 2010.

La reinvención del Estado y el Estado plurinacional. In.:OSAL (Buenos Aires: CLACSO) Año VIII, $\mathrm{N}^{\mathrm{o}}$ 22, Setembro de 2007a. Disponível em: <http://bibliotecavirtual.clacso.org.ar/ar/libros/osal/osal22/D22SousaSantos.pdf $>$. Acessado em 21 de agosto de 2012.

Para uma Concepção Multicultural dos Direitos Humanos. In.: Contexto Internacional. Rio de Janeiro, vol. 23, n. 1, jan/jun, 2001, p. 7-34.

Pensar El Estado Y La Sociedad: desafios actuales. Buenos Aires: Waldhuter Editores. 2009.

Reinventar a Democracia. $2^{\text {a }}$ ed. Lisboa: Gradiva, 1998.

Reinventar a Democracia: entre o pré-contratualismo e o pós-contratualismo. Oficina do Centro de Estudos Sociais. $n^{\circ} 107$. Coimbra, 1998a.

Os Processos de Globalização. In.: SANTOS, Boaventura de Sousa (org.) A Globalização e as Ciências Sociais. São Paulo: Cortez Editora, 2002.

Para uma Concepção Intercultural dos Direitos Humanos. In.: SARMENTO, Daniel e outros (Coord.). Igualdade, Diferença e Direitos humanos. Rio de Janeiro, Lumen Juris, 2008.

Renovar a Teoria Crítica e Reinventar a Emancipação Social. Trad. por BENEDITO, Mouzar. São Paulo: Boitempo, 2005.

"Hablamos Del Socialismo Del Buen Vivir". In.: Sumak Kawsay: recuperar el sentido de vida. ALAI, nº 452, año XXXIV, II época, Quito, Ecuador, febrero 2010a.

SILVA, Heleno Florindo da. Teoria do Estado Plurinacional - o novo constitucionalismo latino-americano e os direitos humanos. Curitiba: Editora Juruá, 2014.

TÁPIA, Luis. Pensando La Democracia Geopolíticamente. La Paz: Muela Del Diablo Editores, 2009.

Tiempo, Poiesis y Modelos de Regularidad. In: Pluralismo Epistemológico. La Paz: Muela del Diablo Editores, 2009a.

TODOROV, Tzvetan. A Conquista da América: a questão do outro. Trad. Por MOISÉS, Beatriz Perrone. 4ªed. São Paulo: Editora WMF Martins Fontes, 2010.

WOLKMER, Antonio Carlos e FAGUNDES, Lucas Machado. Tendências Contemporâneas do Constitucionalismo Latino-Americano: o estado plurinacional e pluralismo jurídico. In: Revista Pensar. Fortaleza, jul. /dez. v. 16. n.2. p. 371-408. 2011.

YRIGOYEN FAJARDO, Raquel Zonia. El Horizonte de Constitucionalismo Pluralista: del multiculturalismo a la descolonización. In.: GARAVITO, César Roberto (Comp.). El Derecho en América Latina: un mapa para el pensamiento jurídico del siglo XXI. Buenos Aires: Siglo Veintiuno, 2011, p. 139-184.

ZIZEK, Slavoj. Contra os Direitos Humanos. Trad. por CAVALCANTE, Sávio. In.: Revista Mediações. V. 15. N. 1. Jan./jun. Londrina, 2010, p. 11-29. 
Trabalho enviado em 08 de dezembro de 2015.

Aceito em 24 de janeiro de 2016. 